\title{
Expression Changes of Long Noncoding RNA in the Process of Endothelial Cell Activation
}

\author{
Min Zhou ${ }^{\mathrm{a}}$ Wen-Jin Ding ${ }^{\mathrm{b}}$ Ying-Wei Chen ${ }^{\mathrm{b}}$ Feng Shen ${ }^{\mathrm{a}} \quad$ Jun-Yi Zeng ${ }^{\mathrm{c}}$ \\ Yun-Feng Weic Chun-Ying $\mathrm{Qu}^{\mathrm{a}}$ Lei-Ming $\mathrm{Xu}^{\mathrm{a}}$ \\ aDepartment of Diagnosis and treatment of digestive endoscopy, Xin Hua Hospital Affiliated to \\ Shanghai Jiao Tong University School of Medicine, Shanghai, 'bepartment of Gastroenterology, Xin \\ Hua Hospital Affiliated to Shanghai Jiao Tong University School of Medicine, Shanghai, 'Department \\ of Cardiology, Jiangxi Institute of Hypertension, the First Affiliated Hospital of Nanchang University, \\ Jiangxi Modern Polytechnic College, Nanchang, China
}

\section{Key Words}

Endothelial cell • Activation • IncRNA • Expression changes

\begin{abstract}
Background: Endothelial cells have been shown to be in response to a variety of local and systemic stimuli, and are able to transition between quiescent and activated states. Endothelial cell activation is critical for the pathogenesis of various cardiovascular diseases. However, the expression changes of long non-coding RNAs (IncRNAs) are still unknown in the process of endothelial cell activation. Thus, this study was aimed to investigate expression changes of IncRNA before and after endothelial cell activation. Materials and Methods: In an experimental model of peripheral venous congestion, endothelial cells were activated and analyzed with Affymetrix HG-U133 plus2.0 microarray. We analyzed these microarray data and reannotated the microarray probes for IncRNA. Results: According to the definition of absolute fold change $>2$ and $p$ value $<0.05,27$ differentially expressed IncRNAs were identified and only 1 IncRNA transcript, ENST00000509256 was down-regualted. Co-expression network of IncRNA and mRNA were constructed to predict function of the dysregulated IncRNA. Gene set enrichment analyses suggested that these ENST00000509256 was associated with many important functions, such as cell-cell signaling and regulation of cell differentiation. Conclusion: Many IncRNAs are dysregulated upon endothelial cell activation and further experiments are needed to identify the potential biological functions of these IncRNAs.

(C) 2017 The Author(s)

Published by S. Karger AG, Basel
\end{abstract}

\section{Introduction}

Vascular endothelial cells locate between the blood and tissues and endothelium is the largest endocrine organ of the body. Vascular endothelial cells lie in the innermost of blood

M. Zhou and W.-J. Ding contributed equally to this work.

\begin{tabular}{ll}
\hline Chun-Ying Qu and Lei-Ming Xu & Kongjiang Road 1665, Shanghai 200092 (China) \\
& Tel. +86-021-65790000, Fax +86-021-65795173 E-Mail 13916823896@163.com and \\
& xuleiminga@foxmail.com
\end{tabular}




\section{Cellular Physiology Cell Physiol Biochem 2017;41:115-123 \begin{tabular}{ll|l} 
and Biochemistry & $\begin{array}{l}\text { DOI: 10.1159/000455980 } \\
\text { Published online: January 18, } 2017\end{array}$ & $\begin{array}{l}\text { ( } 2017 \text { The Author(s). Published by S. Karger AG, Basel } \\
\text { www.karger.com/cpb }\end{array}$ \\
\hline
\end{tabular} \\ Zeng et al.: IncRNA upon Endothelial Activation}

vessels and are vulnerable to stimulus [1,2]. In vitro evidence indicates that the endothelium may become activated and turn into a primary source of pro-inflammatory, vasoconstrictive, and pro-thrombotic mediators in response to biomechanical stress [1-3]. Endothelial cell activation is involved in various pathogenesis of various diseases, such as heart failure and renal failure [4-6].

Inflammation, hemostasis, and other biological and pathological processes are all modulated by the endothelium through transitions between quiescent and activated states that occur in response to environmental stressors [2, 7-9]. Thus, discover the underlying molecular mechanism of endothelial cell activation is of critical importance to develop therapies for heart failure and renal failure.

Long non-coding RNAs (lncRNAs) are RNA transcripts that are larger than 200nt, without protein-coding capacity $[10,11]$. Researchers have focused on protein-coding genes, while IncRNA has been considered as transcription noise and junk RNA. However, recent evidence shows that lncRNAs play important roles in almost every aspect of physiological processes, such as differentiation, proliferation, apoptosis, and inflammation [12-17]. However, the expression profile and function of lncRNA are still unknown in the process of endothelial cell activation.

Colombo PC developed an experimental model of acute, peripheral venous congestion in healthy human subjects and found endothelial cells were activated [3]. With microarray technology, they investigated gene expression of endothelial cells before and after venous congestion. Here, we re-annotated the microarray probe sets and profiled lncRNA expression changes after endothelial cell activation.

\section{Materials and Methods}

\section{Peripheral venous congestion model}

The detailed methods were described by Colombo PC [9]. Briefly, 24 healthy subjects were enrolled. Blood and endothelial cells were sampled from the antecubital or basilic vein of the non-dominant arm (control arm) at baseline and of the dominant arm (test arm) after $75 \mathrm{~min}$ of local venous congestion using angiocatheters and endovascular wires. Peripheral venous pressure was increased $30 \mathrm{mmHg}$ above baseline levels by inflating a tourniquet cuff around the test arm, proximally, just below the shoulder. Blood was also obtained at 75 min from the control arm which was not exposed to venous congestion, thus serving as a control [3]. Magnetic beads coated with EC-specific antibodies were used to separate endothelial cells.

\section{Microarray data processing}

The raw microarray data was downloaded from the gene expression omnibus (GE0) database and this dataset could be accessed by the accession number GSE38783. In accordance with Colombo PC [9], the raw files of first normalized using the log scale robust multi-array analysis with default settings [18]. And differentially expressed lncRNAs between after vs. before experiments were calculated using paired $t$-test. Heatmap of differentially expressed IncRNAs was generated by Cluster (V3.0) software.

\section{LncRNA annotation pipeline}

The Affymetrix human genome U133 Plus2.0 microarray was used in this study. Annotation of the HGU133 Plus 2.0 was downloaded from the BioMart database. Only probes that were annotated as lncRNA were selected and transcript ID, chromosome location, strand, biologic types, and other annotation information were also downloaded.

LncRNA-mRNA co-expression network

We built lncRNA-mRNA-network to identify the interactions between mRNA and IncRNA [19]. LncRNAmRNA network was built according to the normalized signal intensity of specific expression of mRNA and IncRNA. For each pair of mRNA-IncRNA, mRNA-mRNA or IncRNA-lncRNA, we calculated the Pearson correlation and choose the significant correlation pairs $(P<0.05)$ with which to construct the network [20]. 


\section{Cellular Physiology Cell Physiol Biochem 2017;41:115-123

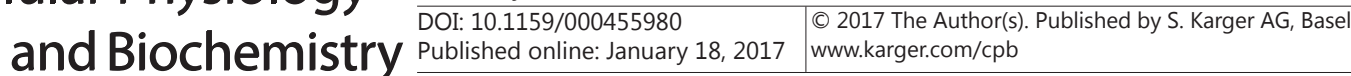 \\ Zeng et al.: IncRNA upon Endothelial Activation}

Gene set enrichment analysis (GSEA)

GSEA is a computational method that determines whether a priori defined set of genes shows statistically significant concordant differences between two biological states [21, 22]. GSEA is a powerful analytical method for interpreting gene expression data and GSEA focuses on genes that share common biological function, chromosomal location, or regulation. Samples were categorized as high expression and low expression according to ENST00000509256 expression and GSEA was performed by the GSEA desktop application with default parameters.

\section{Results}

Raw data of 24 samples (12 controls and 12 venous congestion samples) were downloaded from the GEO database. Primary quality of the 24 microarrays was assessed by normalized unscaled standard error (NUSE) algorithm and we found that boxplots of NUSE values were centered around 1, indicating the microarray data were of high quality(Fig. 1A).

Then differentially expressed probes were calculated and 3437 probes were identified with the threshold $P<0.05$, which was consistent with Colombo's report. Then we annotated these probes for IncRNAs using the annotation file we built. With the $P<0.05$ and absolute fold change $(F C)>1.5,227$ differentially expressed lncRNAs were identified (Fig. 1B). List of 227 differentially expressed lncRNAs are shown in supplementary file, see www.karger.com/ doi/10.1159/000455980). Among the 227 lncRNAs, there are 27 lncRNAs with absolute FC>

Fig. 1. Quality check of the microarrays analyzed (a) the NUSE values of microarrays were around 1 , showing the microarrays were of high quality; heatmap of 227 differentially expressed IncRNAs, red: up-regulation, green: down-regualtion (b); heatmap of 27 differentially expressed lncRNAs, yellow: up-regulation, blue: down-regulation (c).

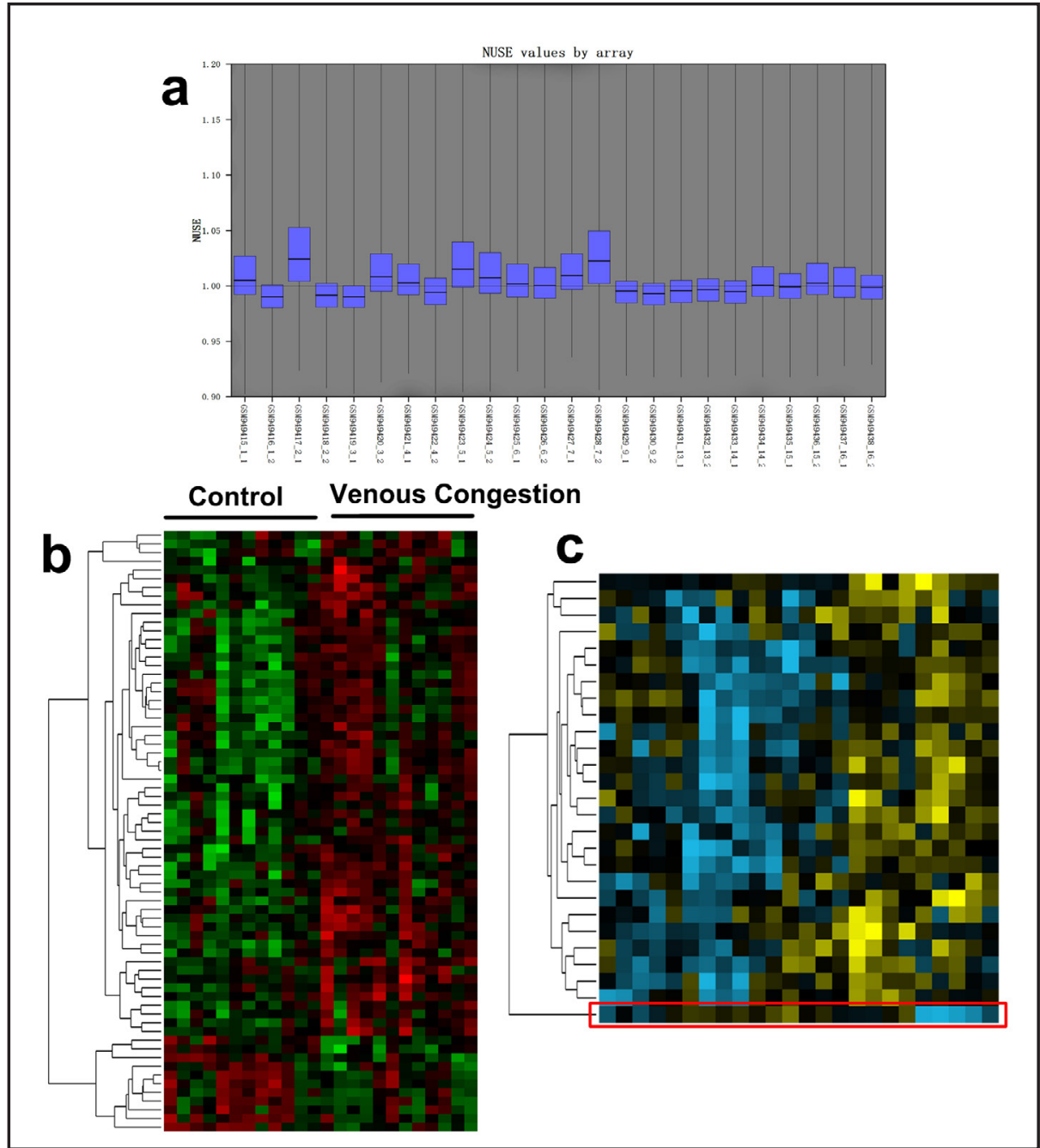




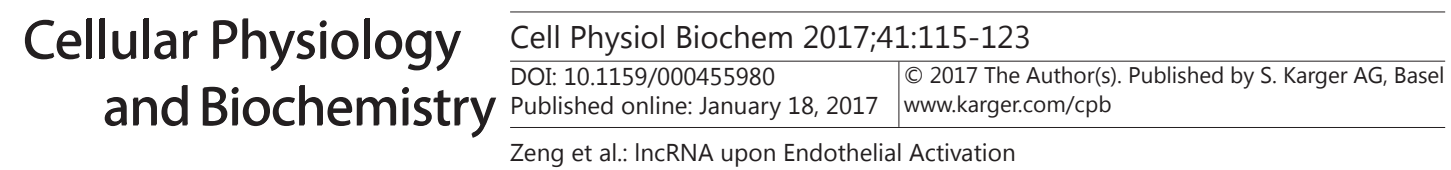

Table 1. 27 differentially expressed lncRNAs with absolute fold change 2. FC: fold change

\begin{tabular}{|c|c|c|c|c|c|}
\hline Ensembl Transcript ID & $\mathrm{FC}$ & Chromosome Name & Strand & Transcript Start & Transcript End \\
\hline ENST00000562811 & 2.56 & 1 & -1 & 119597702 & 119599271 \\
\hline ENST00000482945 & 2.28 & 15 & -1 & 58597165 & 58621504 \\
\hline ENST00000497699 & 2.10 & 10 & 1 & 28677510 & 28682677 \\
\hline ENST00000603679 & 2.36 & 1 & 1 & 100735175 & 100739039 \\
\hline ENST00000473385 & 2.02 & 1 & 1 & 211368929 & 211374785 \\
\hline ENST00000464213 & 2.05 & 7 & 1 & 80665914 & 80679277 \\
\hline ENST00000296031 & 2.57 & 4 & -1 & 74097676 & 74099195 \\
\hline ENST00000464961 & 2.10 & 3 & -1 & 33496245 & 33505451 \\
\hline ENST00000497089 & 2.25 & 7 & -1 & 27162600 & 27169444 \\
\hline ENST00000535593 & 2.22 & 12 & 1 & 21501781 & 21516231 \\
\hline ENST00000633364 & 2.45 & 2 & -1 & 110465051 & 110472816 \\
\hline ENST00000465128 & 2.40 & $\mathrm{X}$ & -1 & 134771897 & 134789104 \\
\hline ENST00000479608 & 2.05 & 12 & 1 & 45836761 & 45908040 \\
\hline ENST00000556027 & 2.07 & 14 & -1 & 53046027 & 53093664 \\
\hline ENST00000521168 & 2.42 & 8 & 1 & 67157627 & 67195518 \\
\hline ENST00000462273 & 2.13 & 14 & 1 & 104049418 & 104052665 \\
\hline ENST00000602461 & 2.17 & $\mathrm{X}$ & -1 & 45745211 & 45770274 \\
\hline ENST00000561973 & 2.06 & $\mathrm{X}$ & -1 & 68013470 & 68014901 \\
\hline ENST00000509256 & -2.00 & 5 & 1 & 32052494 & 32057949 \\
\hline ENST00000484083 & 2.16 & 10 & -1 & 68341130 & 68376946 \\
\hline ENST00000523031 & 2.03 & 8 & -1 & 143280161 & 143280849 \\
\hline ENST00000565283 & 2.22 & 2 & -1 & 36354749 & 36355114 \\
\hline ENST00000490320 & 2.06 & 3 & 1 & 160225797 & 160228054 \\
\hline ENST00000605506 & 2.32 & 1 & -1 & 84076331 & 84077931 \\
\hline ENST00000488625 & 2.14 & 10 & 1 & 31318495 & 31529202 \\
\hline ENST00000606008 & 2.24 & 3 & 1 & 44667412 & 44669364 \\
\hline ENST00000601365 & 2.26 & 19 & -1 & 20004420 & 20008188 \\
\hline
\end{tabular}

2 (Table 1). Heatmap of the 27 lncRNAs were shown in Figure 1C. Intriguingly, among the 27 lncRNAs with absolute FC> 2, only 1 lncRNA (ENST00000509256) was down-regulated.

Among the 227 differentially expressed lncRNAs, the 4 most common types were processed transcript, retained intron, large introgenic RNA, and antisense RNA. It has been proposed that genes with the same function or in the same pathway would be co-expressed. And co-expressed network has been used to predict potential function of lncRNAs based on this hypothesis. For example, the function of a novel lncRNA in hepatocellular cell carcinoma was predicted by IncRNA-mRNA co-expression network [23]. Thus, we constructed lncRNAmRNA co-expression network for the differentially expressed lncRNAs (Fig. 2B). Many genes with important regulatory functions were co-expressed with IncRNA, such as WDR20, DCAF8, PDSS2, SMEK2, EIF3A, HNRNPH2, SPRY2, STAU2, LHX2, RIF1 and CDK13, indicating these IncRNAs may also have critical regulatory potency. As shown, IncRNA ENST00000482945 was co-expressed with most mRNAs.

As mentioned, only ENST00000509256 was down-regulated among the 27 IncRNAs. Then we tried to predict its biological functional with further bioinformatics methods. GSEA is a useful method for predicting functions of unknown genes has been widely used by many studies. The most positively correlated gene ontology (GO) items and KEGG pathways were 
Fig. 2. Biological types of 227 differentially expressed IncRNAs (a); co-exp ress i o n network between IncRNA and mRNA (b), yellow: IncRNA; blue: mRNA; red line: positive correlation; green line: negative correlation.

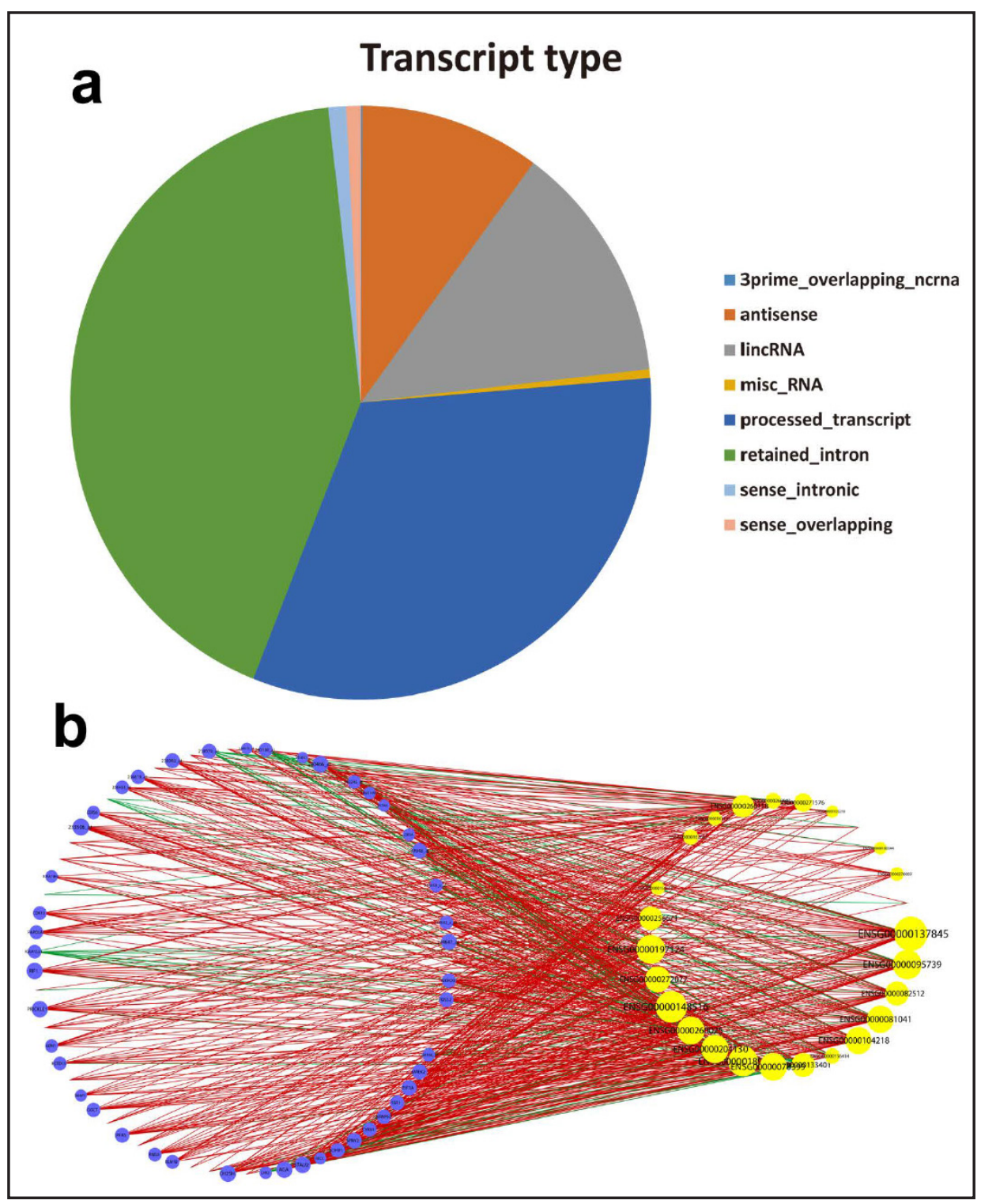

shown in Figure 3. According to GSEA results, the most correlated GO item was cell-cell signaling and the most positively correlated KEGG pathway was intracellular transport. The GO items and KEGG pathways that were most negatively correlated with ENST00000509256 were shown in Figure 4. As shown the most correlated GO item was neuroactive ligand receptor interaction and the most negatively correlated KEGG pathway was oxidative phosphorylation.

\section{Discussion}

Endothelial cells have been shown to be phenotypically dynamic and, in response to a variety of local and systemic stimuli, are able to transition between quiescent and activated states $[1,2]$. In recent years, emerging research has demonstrated that endothelial dysfunction is a major contributor to cardiovascular disease, including hypertension, atherosclerosis, and more recently, congestive heart failure [7, 8]. Activation of endothelial cells causes endothelial cells to undergo a phenotypic switch to a pro-oxidant, pro-inflammatory, vasoconstricted state $[13,14]$. By the experimental model, Colombo PC has proved that venous congestion led to endothelial cell activation and releases of inflammatory mediators 


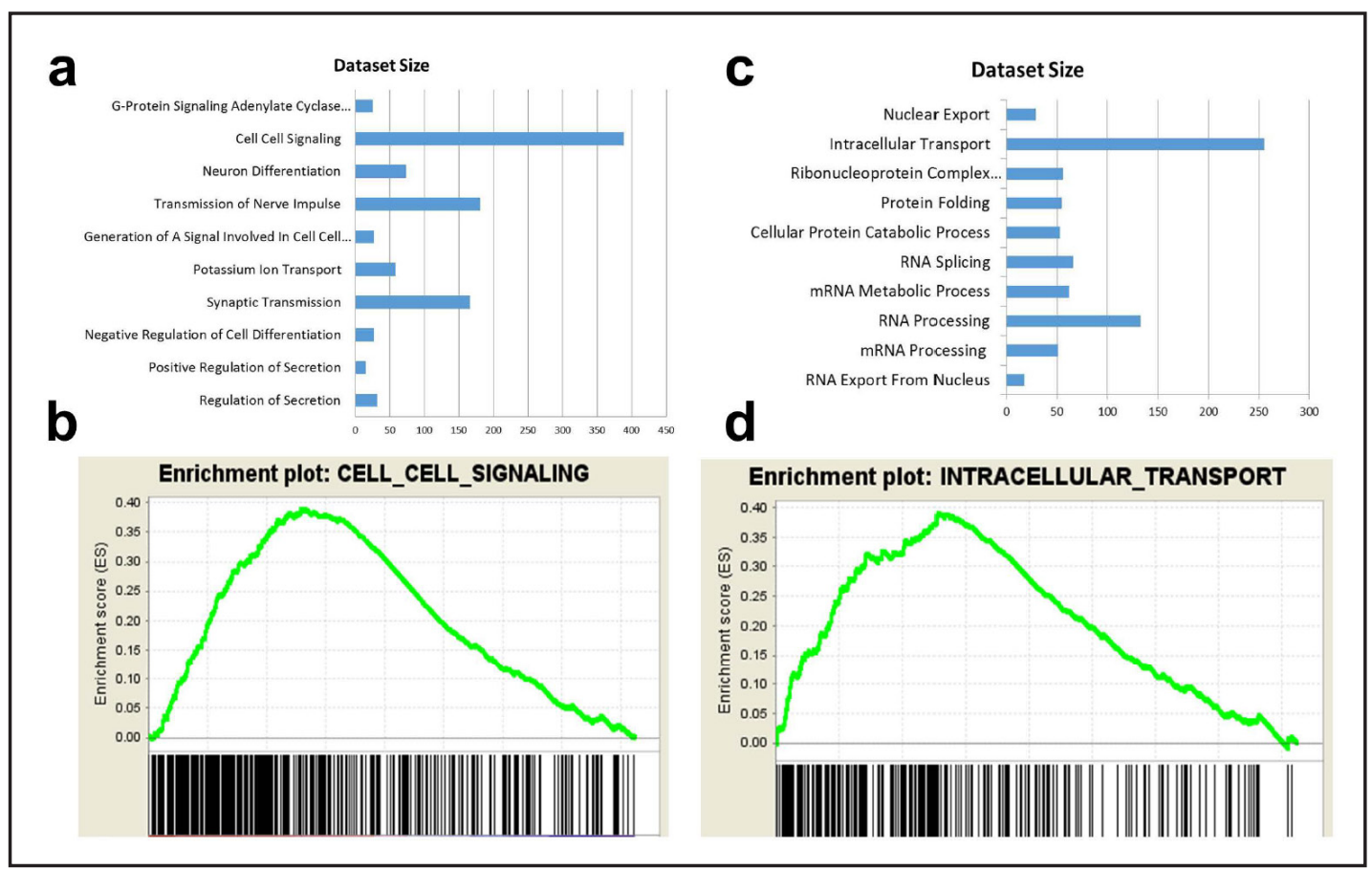

Fig. 3. Positively enriched GO (a, b) and KEGG (c, d) items by ENST00000509256 (a,c: enriched datasets; b, d: enrichment plot).

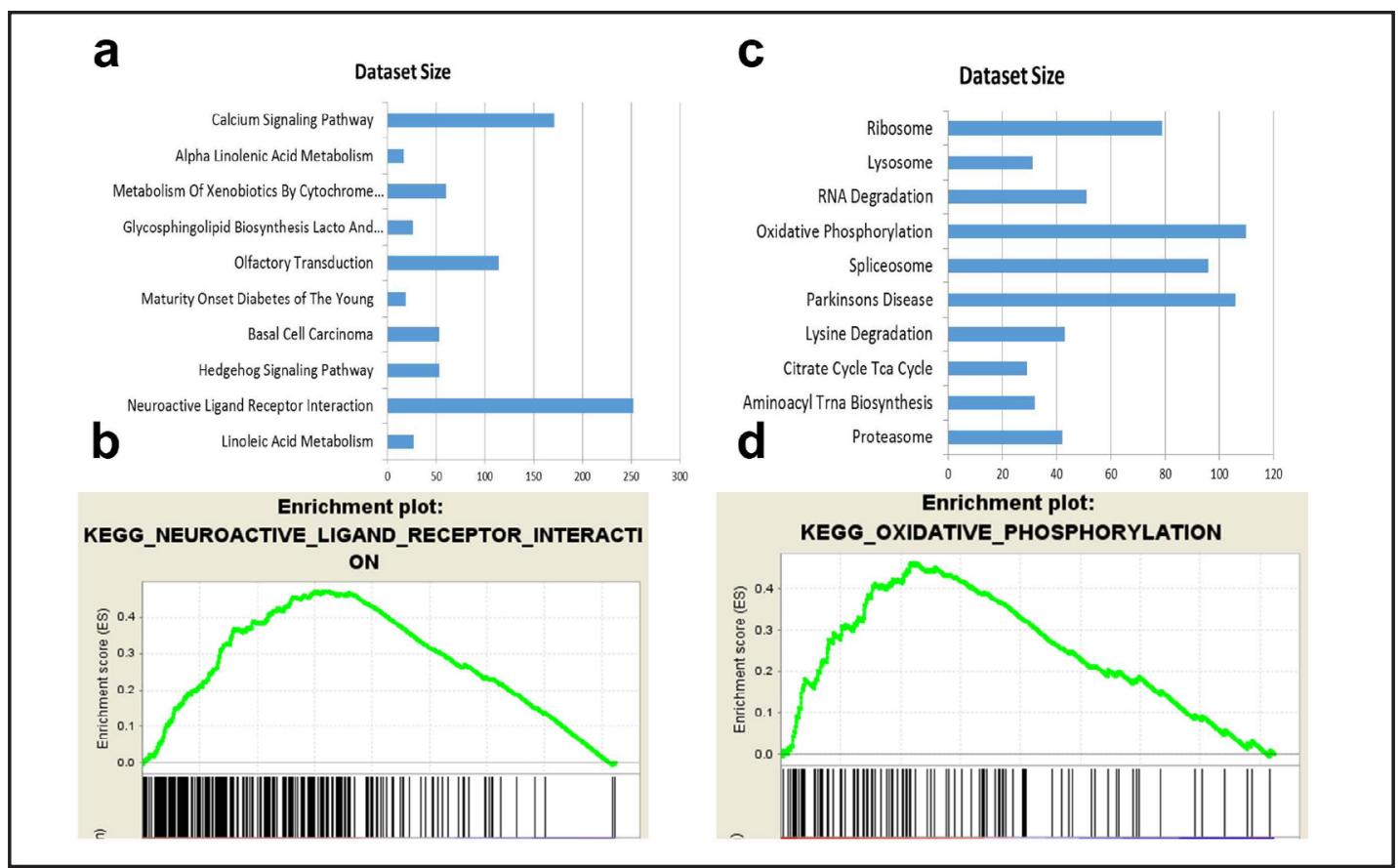

Fig. 4. Negatively enriched GO (a, b) and KEGG (c, d) items by ENST00000509256 (a,c: enriched datasets; b, d: enrichment plot).

and neurohormones [1, 2]. However, the expression changes of lncRNA are still unknown.

It has been proved that noncoding RNAs are involved in many human diseases by altering gene expression at different levels [11, 24-26]. MicroRNAs and lncRNAs are the 2 types of most investigated noncoding RNAs in cardiovascular diseases [27-30]. The functional regulatory roles of microRNAs have been extensively investigated in cardiovascular diseases, 


\section{Cellular Physiology Cell Physiol Biochem 2017;41:115-123 \\ \begin{tabular}{ll|l} 
DOI: 10.1159/000455980 & $\begin{array}{l}\text { O 2017 The Author(s). Published by S. Karger AG, Basel } \\
\text { www.karger.com/cpb }\end{array}$ \\
\hline
\end{tabular} \\ Zeng et al.: IncRNA upon Endothelial Activation}

particular in atherosclerosis [27-29, 31, 32]. Mounting evidence has proved that microRNAs control the senescence and dysfunction of endothelial cells, proliferation and migration of vascular smooth muscle cells, and macrophage-drive cytokine production [33]. Among these endothelial microRNAs, the functional roles of miR-126 and miR-143/145 have been well documented [27]. Endothelial cells injury and repair are the fundamental elements in the pathophysiology of atherogenesis. Several miRs have been implicated in modification of vessel restenosis after interventional endothelial injury. Knockout of miR-21 can attenuate neointimal formation post-stenting in a mouse vascular stent model [34] and in vivo administration of antagomiRs and miR mimetics also shows beneficial effects on cardiac remodeling $[35,36]$. In addition to microRNAs, IncRNAs are also involved in restenosis and vascular remodeling $[37,38]$.

LncRNAs are emerging as regulators of vascular function in health and disease[37]. Functions of currently known lncRNAs can be classified as followings: 1) scaffold or guide for epigenetic and transcription factors; 2) imprinting; 3) enhancer activation; 4) molecular sponges [24, 39]. For cardiovascular diseases, several IncRNAs have been reported. For example, it has been reported that IncRNA H19 and ANRIL play important roles in atherosclerosis development $[40,41]$. Since lncRNAs are complex in both their sheer numbers and mechanisms of action, identifying their contribution to vascular disease is challenging and investigation of lncRNAs in endothelial cells is rare.

In the current study, we systematically investigated lncRNA expression changes in endothelial cells upon venous congestion by analyzing microarray data. The experimental models successfully activated endothelial cells since the levels pro-inflammatory cytokines increased in the congested arm and the mRNA expressions of ET-1, VCAM-1 and CXCL2 also increased [3]. Therefore, the differentially expressed lncRNAs we identified could represent changes of IncRNA expression upon endothelial cell activation. By calculation, we identified 227 differentially expressed lncRNAs. The most 2 common transcript types were processed transcripts and retained intron in our results, which was different from reports from other diseases [42]. The reason may be the annotation files were based on different databases. Then we found there were 27 IncRNAs with absolute fold change $>2$. Co-expression network were constructed for the 27 lncRNAs and we found many important mRNAs were co-expressed with lncRNAs, suggesting these lncRNAs might have vital biological functions. Notably, there is only 1 down-regualted lncRNA, ENST00000509256 among the 27 lncRNAs and GSEA methods were utilized to predict its potential biological function. GSEA results showed that ENST00000509256 was associated with biological functions, like cell-cell signaling and neuroactive ligand receptor interaction. These items are related with inflammation and it is possible that ENST00000509256 is involved the inflammatory processes upon endothelial activation.

Re-annotation and data mining of published dataset is a feasible and cost-effective method to analyze lncRNA expression profile and identify functional lncRNAs. However, findings of our study should be further validated by cellular experiments. Additionally, the microarray we analyzed was not specially designed to detect lncRNA expression. Thus only small parts of lncRNA were analyzed in this work and further comprehensive studies are warranted.

To summary, we systematically analyzed lncRNA expression changes of endothelial activation in the venous congestion experimental model, and further experiments are needed to identify the potential biological functions of these lncRNAs.

\section{Acknowledgements}

This work was funded by the Scientific Research Project of Shanghai Science and Technology Commission (No. 16DZ1930603). 


\section{Cellular Physiology Cell Physiol Biochem 2017;41:115-123

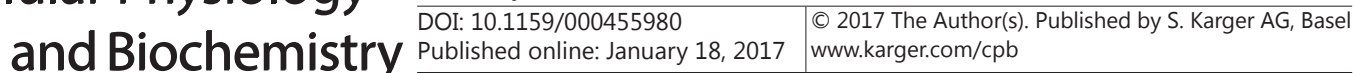 \\ Zeng et al.: IncRNA upon Endothelial Activation}

\section{Disclosure Statement}

The authors have declared no conflict of interest.

\section{References}

-1 Ganda A, Onat D, Demmer RT, Wan E, Vittorio TJ, Sabbah HN, Colombo PC: Venous congestion and endothelial cell activation in acute decompensated heart failure. Curr Heart Fail Rep 2010,7:66-74.

2 Colombo PC, Doran AC, Onat D, Wong KY, Ahmad M, Sabbah HN, Demmer RT: Venous congestion, endothelial and neurohormonal activation in acute decompensated heart failure: cause or effect? Curr Heart Fail Rep 2015,12:215-222.

-3 Colombo PC, Onat D, Harxhi A, Demmer RT, Hayashi Y, Jelic S, LeJemtel TH, Bucciarelli L, Kebschull M, Papapanou P, Uriel N, Schmidt AM, Sabbah HN, Jorde UP: Peripheral venous congestion causes inflammation, neurohormonal, and endothelial cell activation. Eur Heart J 2014,35:448-454.

4 Gutierrez E, Flammer AJ, Lerman LO, Elizaga J, Lerman A, Fernandez-Aviles F: Endothelial dysfunction over the course of coronary artery disease. Eur Heart J 2013,34:3175-3181.

-5 Marti CN, Gheorghiade M, Kalogeropoulos AP, Georgiopoulou VV, Quyyumi AA, Butler J: Endothelial dysfunction, arterial stiffness, and heart failure. J Am Coll Cardiol 2012,60:1455-1469.

6 Rajendran P, Rengarajan T, Thangavel J, Nishigaki Y, Sakthisekaran D, Sethi G, Nishigaki I: The vascular endothelium and human diseases. Int J Biol Sci 2013,9:1057-1069.

7 Vane JR, Anggard EE, Botting RM: Regulatory functions of the vascular endothelium. N Engl J Med 1990,323:27-36. Aird WC: Mechanisms of endothelial cell heterogeneity in health and disease. Circ Res 2006,98:159-162. Gimbrone MA, Jr., Topper JN, Nagel T, Anderson KR, Garcia-Cardena G: Endothelial dysfunction, hemodynamic forces, and atherogenesis. Ann N Y Acad Sci 2000,902:230-239.

$\checkmark 10$ Ponting CP, Oliver PL, Reik W: Evolution and functions of long noncoding RNAs. Cell 2009,136:629-641. Esteller M: Non-coding RNAs in human disease. Nat Rev Genet 2011,12:861-874.

Khaitan D, Dinger ME, Mazar J, Crawford J, Smith MA, Mattick JS, Perera RJ: The melanoma-upregulated long noncoding RNA SPRY4-IT1 modulates apoptosis and invasion. Cancer Res 2011,71:3852-3862.

13 Huarte M, Guttman M, Feldser D, Garber M, Koziol MJ, Kenzelmann-Broz D, Khalil AM, Zuk O, Amit I, Rabani M, Attardi LD, Regev A, Lander ES, Jacks T, Rinn JL: A large intergenic noncoding RNA induced by p53 mediates global gene repression in the 53 response. Cell 2010,142:409-419.

14 Tian D, Sun S, Lee JT: The long noncoding RNA, Jpx, is a molecular switch for X chromosome inactivation. Cell 2010,143:390-403.

15 Wapinski O, Chang HY: Long noncoding RNAs and human disease. Trends Cell Biol 2011,21:354-361. Yin DD, Zhang EB, You LH, Wang N, Wang LT, Jin FY, Zhu YN, Cao LH, Yuan QX, De W, Tang W: Downregulation of lncRNA TUG1 affects apoptosis and insulin secretion in mouse pancreatic beta cells. Cell Physiol Biochem 2015,35:1892-1904.

17 Li J, Long W, Li Q, Zhou Q, Wang Y, Wang H, Zhou B, Li J: Distinct expression profiles of lncRNAs between regressive and mature scars. Cell Physiol Biochem 2015,35:663-675.

-18 Bolstad BM, Irizarry RA, Astrand M, Speed TP: A comparison of normalization methods for high density oligonucleotide array data based on variance and bias. Bioinformatics 2003,19:185-193.

19 Pujana MA, Han JD, Starita LM, Stevens KN, Tewari M, Ahn JS, Rennert G, Moreno V, Kirchhoff T, Gold B, Assmann V, Elshamy WM, Rual JF, Levine D, Rozek LS, Gelman RS, Gunsalus KC, Greenberg RA, Sobhian B, Bertin N, Venkatesan K, Ayivi-Guedehoussou N, Sole X, Hernandez P, Lazaro C, Nathanson KL, Weber BL, Cusick ME, Hill DE, Offit K, Livingston DM, Gruber SB, Parvin JD, Vidal M: Network modeling links breast cancer susceptibility and centrosome dysfunction. Nat Genet 2007,39:1338-1349.

20 Prieto C, Risueno A, Fontanillo C, De las Rivas J: Human gene coexpression landscape: confident network derived from tissue transcriptomic profiles. PLoS One 2008,3:e3911.

21 Subramanian A, Tamayo P, Mootha VK, Mukherjee S, Ebert BL, Gillette MA, Paulovich A, Pomeroy SL, Golub TR, Lander ES, Mesirov JP: Gene set enrichment analysis: a knowledge-based approach for interpreting genome-wide expression profiles. Proc Natl Acad Sci U S A 2005,102:15545-15550. 


\section{Cellular Physiology Cell Physiol Biochem 2017;41:115-123 \begin{tabular}{ll|l} 
DOI: 10.1159/000455980 & $\begin{array}{l}\text { O 2017 The Author(s). Published by S. Karger AG, Basel } \\
\text { www.karger.com/cpb }\end{array}$ \\
\hline
\end{tabular} \\ Zeng et al.: IncRNA upon Endothelial Activation}

-22 Mootha VK, Lindgren CM, Eriksson KF, Subramanian A, Sihag S, Lehar J, Puigserver P, Carlsson E, Ridderstrale M, Laurila E, Houstis N, Daly MJ, Patterson N, Mesirov JP, Golub TR, Tamayo P, Spiegelman B, Lander ES, Hirschhorn JN, Altshuler D, Groop LC: PGC-1alpha-responsive genes involved in oxidative phosphorylation are coordinately downregulated in human diabetes. Nat Genet 2003,34:267-273.

-23 Yang F, Zhang L, Huo XS, Yuan JH, Xu D, Yuan SX, Zhu N, Zhou WP, Yang GS, Wang YZ, Shang JL, Gao CF, Zhang FR, Wang F, Sun SH: Long noncoding RNA high expression in hepatocellular carcinoma facilitates tumor growth through enhancer of zeste homolog 2 in humans. Hepatology 2011,54:1679-1689. Uchida S, Dimmeler S: Long noncoding RNAs in cardiovascular diseases. Circ Res 2015,116:737-750. Van Roosbroeck K, Pollet J, Calin GA: miRNAs and long noncoding RNAs as biomarkers in human diseases. Expert Rev Mol Diagn 2013,13:183-204.

26 Shi Z, Zhao C, Long W, Ding H, Shen R: Microarray Expression Profile Analysis of Long Non-Coding RNAs in Umbilical Cord Plasma Reveals their Potential Role in Gestational Diabetes-Induced Macrosomia. Cell Physiol Biochem 2015,36:542-554.

27 Santulli G: microRNAs Distinctively Regulate Vascular Smooth Muscle and Endothelial Cells: Functional Implications in Angiogenesis, Atherosclerosis, and In-Stent Restenosis. Adv Exp Med Biol 2015,887:53-77.

28 Santulli G: MicroRNAs and Endothelial (Dys) Function. J Cell Physiol 2016,231:1638-1644.

29 Novak J, Olejnickova V, Tkacova N, Santulli G: Mechanistic Role of MicroRNAs in Coupling Lipid Metabolism and Atherosclerosis. Adv Exp Med Biol 2015,887:79-100.

-30 Liu Y, Zhou D, Li G, Ming X, Tu Y, Tian J, Lu H, Yu B: Long non coding RNA-UCA1 contributes to cardiomyocyte apoptosis by suppression of p27 expression. Cell Physiol Biochem 2015,35:1986-1998.

- 31 Wronska A, Kurkowska-Jastrzebska I, Santulli G: Application of microRNAs in diagnosis and treatment of cardiovascular disease. Acta Physiol (Oxf) 2015,213:60-83.

-32 Santulli G, Wronska A, Uryu K, Diacovo TG, Gao M, Marx SO, Kitajewski J, Chilton JM, Akat KM, Tuschl T, Marks AR, Totary-Jain H: A selective microRNA-based strategy inhibits restenosis while preserving endothelial function. J Clin Invest 2014,124:4102-4114.

33 Gao Y, Peng J, Ren Z, He NY, Li Q, Zhao XS, Wang MM, Wen HY, Tang ZH, Jiang ZS, Wang GX, Liu LS: Functional regulatory roles of microRNAs in atherosclerosis. Clin Chim Acta 2016,460:164-171.

-34 McDonald RA, Halliday CA, Miller AM, Diver LA, Dakin RS, Montgomery J, McBride MW, Kennedy S, McClure JD, Robertson KE, Douglas G, Channon KM, Oldroyd KG, Baker AH: Reducing In-Stent Restenosis: Therapeutic Manipulation of miRNA in Vascular Remodeling and Inflammation. J Am Coll Cardiol 2015,65:2314-2327.

- 35 van Rooij E, Sutherland LB, Thatcher JE, DiMaio JM, Naseem RH, Marshall WS, Hill JA, Olson EN: Dysregulation of microRNAs after myocardial infarction reveals a role of miR-29 in cardiac fibrosis. Proc Natl Acad Sci U S A 2008,105:13027-13032.

-36 Care A, Catalucci D, Felicetti F, Bonci D, Addario A, Gallo P, Bang ML, Segnalini P, Gu Y, Dalton ND, Elia L, Latronico MV, Hoydal M, Autore C, Russo MA, Dorn GW, 2nd, Ellingsen O, Ruiz-Lozano P, Peterson KL, Croce CM, Peschle C, Condorelli G: MicroRNA-133 controls cardiac hypertrophy. Nat Med 2007,13:613-618.

- 37 Deng L, Bradshaw AC, Baker AH: Role of noncoding RNA in vascular remodelling. Curr Opin Lipidol 2016.

- 38 Leung A, Stapleton K, Natarajan R: Functional Long Non-coding RNAs in Vascular Smooth Muscle Cells. Curr Top Microbiol Immunol 2016,394:127-141.

39 Ounzain S, Crippa S, Pedrazzini T: Small and long non-coding RNAs in cardiac homeostasis and regeneration. Biochim Biophys Acta 2013,1833:923-933.

-40 Li L, Xie J, Zhang M, Wang S: Homocysteine harasses the imprinting expression of IGF2 and H19 by demethylation of differentially methylated region between IGF2/H19 genes. Acta Biochim Biophys Sin (Shanghai) 2009,41:464-471.

41 Holdt LM, Hoffmann S, Sass K, Langenberger D, Scholz M, Krohn K, Finstermeier K, Stahringer A, Wilfert W, Beutner F, Gielen S, Schuler G, Gabel G, Bergert H, Bechmann I, Stadler PF, Thiery J, Teupser D: Alu elements in ANRIL non-coding RNA at chromosome 9p21 modulate atherogenic cell functions through transregulation of gene networks. PLoS Genet 2013,9:e1003588.

-42 Yu TT, Xu XM, Hu Y, Deng JJ, Ge W, Han NN, Zhang MX: Long noncoding RNAs in hepatitis B virus-related hepatocellular carcinoma. World J Gastroenterol 2015,21:7208-7217. 